\title{
Serous Cystadenocarcinoma
}

National Cancer Institute

\section{Source}

National Cancer Institute. Serous Cystadenocarcinoma. NCI Thesaurus. Code C3778.

A malignant serous cystic neoplasm usually involving the ovary or the pancreas. It is characterized by the presence of invasive malignant glandular epithelial cells which often form papillary structures. 